\title{
REVIEW
}

\section{EFFECTIVE COMMUNICATION AND SHARING INFORMATION AT CLINICAL HANDOVERS}

\author{
Radka Pokojová, Sylva Bártlová \\ Institute of Nursing, Midwifery and Emergency Care, Faculty of Health and Social Sciences, University of South Bohemia in \\ České Budějovice, Czech Republic
}

Received February 14, 2018; Accepted June 14, 2018. Copyright: This is an open access article distributed under the terms of the Creative Commons Attribution International License (CC BY). http://creativecommons.org/licenses/by/4.0/

\begin{abstract}
Aim: The aim of this study was to present an overview of current knowledge of approaches to improving patient safety and to ensuring continuity of care at clinical information handovers (handoffs). Design: Descriptive summarizing study. Methods: PubMed, Science Direct, Embase and Google Scholar databases were studied, focusing on papers published in English over the past five years. The overview included papers dealing with the effectiveness of patient information transfer between members of staff, teams, and healthcare providers. After classification of materials, 28 articles were finally analyzed. Results: The tools for information handovers were mostly (i.e., in 18 instances) based on the mnemonic SBAR list. To a lesser extent, IPASS technology, the structure of body systems, and a checklist for trauma patients were used. The quality of transferred information was most frequently assessed at ICUs. Conclusion: The implementation of structured approaches for both oral and written information on patients is problematic, but the authors agree that it is necessary to take into account the particular conditions and context of communication.
\end{abstract}

Keywords: care continuity, information handover/handoff, patient safety, standardization.

\section{Introduction}

In increasingly sophisticated healthcare systems, use of modern technologies can increase the risks associated with patient information handovers, as this influences the means of communication, degree of mutual understanding and ambiguity of reports. It may be difficult to ensure the transfer of basic information between healthcare providers due to the dispersal of clinical and professional responsibilities among various healthcare team members.

The field of patient information handovers, patient transmissions, and continuity of care had become so important by 2008 that Joint Commission International (JCI) included handoffs in the National Goal of ensuring patient safety (Friesen, White, Byers, 2008; Halm, 2013). Patient clinical handover or transfer includes both the transmission of and assumption of responsibility for patient care, which can be achieved by effective communication. It means the handover of specific information about the patient in real time, taking place between nurses or nursing teams, to ensure the continuity and safety

Corresponding author: Radka Pokojová, Institute of Nursing, Midwifery and Emergency Care, Faculty of Health and Social Sciences, University of South Bohemia in České Budějovice, J. Boreckého 1167/27, České Budějovice, Czech Republic; email: radka.pokojova@centrum.cz. of patient care (Cohen, Hilligoss, 2010).

The term clinical handover (handoff) is used for handover of patient information between two shifts, in cases when the health status of a patient deteriorates, and at the handover of a patient from or to a higher level of care (e.g. from an ambulance to an urgent care facility) and is closely associated with the handover of control and responsibility. Another term - transfer - is used for the handover of patients and related responsibilities to a department with a different specialization within a hospital. The term clinical handover distinguishes the standard routine of communication from the more complex reviews during ward rounds or other more concentrated communications, such as consultations (Cohen, Hilligoss, 2010). In 2008, JCI processed requirements that should contribute to achieving goals in the area of patient safety at hospitals:

Interactive communication between the person handing over patient information and the recipient of the information, providing a chance to ask questions.

Topical information on nursing and medical care, and services provided to patients, their health status, and any recent or expected changes.

Process of verifying accepted information, including its repetition or, if necessary, re-reading. 
Opportunities for information recipients to find out relevant historical data on patients that might include previous nursing and medical treatment, and services. Interruptions in the course of handovers are kept to a minimum to reduce the possibility that information will not be transferred or will be forgotten (Friesen, White, Byers, 2008).

In the Czech Republic, the requirement of ensuring patient safety during transfers and handovers is laid down in Regulation $\S 47$, par. 3 (b), Act 372/2011 on health services and conditions for their provision. (Zákon 372/2011) A detailed methodology and requirements are published in the Bulletin of the Ministry of Health, No. 16/2015 as Sectoral Safety Goal 7 - Safe Patient Handovers (Věstník 16/2015). Within the National System of Reporting Adverse Events in the Czech Republic, the adverse events associated with patient transfers and handovers can be included under the category of clinical administration, and, according to specific events, under the categories of clinical intervention, records and sources/management of the organization (Pokorná et al., 2017).

Implementation of the goal: Patient safety at handovers requires organizations to introduce a standardized approach to communication at handovers, providing opportunities to ask and answer questions (Friesen, White, Byers, 2008; Cohen, Hilligoss, 2010). However, according to Cohen, Hilligoss (2010), it is not entirely clear what should be included in the handover, how the concept of standardization should be interpreted, and how great the safety gains for a patient can be reliably expected to be from improvements in transmission of information. Some concern has been expressed over possible unintended consequences of a standardized approach, and attention has been drawn to the fact that pre-prepared checklists do not enable classification according to level of importance and might be used instead of verbal updates in busy periods. A developed template can change the character of the whole process from a bilateral interaction to a unilateral transaction. As a result, patient safety can be impaired, and fewer questions asked and explained (Perry, Wears, Patterson, 2008). For difficult situations, e.g. uncertain diagnoses or uncertain course of the disease, a system describing the development in time, interconnecting specific events, and emphasizing their interrelations would appear to be more effective (Horsky et al., 2015).

The complexity of these processes is also confirmed by a study performed by Machaczek et al. (2013) in the Czech Republic. The results suggest that the insufficient quality of medical handover records has a particularly negative impact on information handover. Social relationships and differences in the status of clinicians can also have a negative impact on handovers. While handovers are strongly influenced by context, results show that work settings do not support clinical staff's efforts to perform handovers effectively. Though nursing handovers are performed in a more standardized way than medical handovers, results do not support the idea that standardization improves the level of information provided. Lack of time, poor planning with regard to staffing, and interruptions in work processes have proven to be the main obstacles.

An extensive questionnaire study performed by the Faculty of Healthcare and Social Studies, South Bohemian University, České Budějovice found that $43.9 \%$ of staff nurses admitted to problems with information exchange between hospital wards, $88.0 \%$ did not believe that information was lost during shift handovers, and $84.1 \%$ did not believe that information was lost during transfers of patient to other wards (Brabcová et al., 2015).

\section{Aim}

The aim of this study is to present a current overview of lessons learned regarding approaches to increasing patient safety and ensuring continuity of care during clinical transmission and transfers, and risk reduction initiatives and their results.

We decided to study this sectoral safety goal in the belief that it is difficult to ensure the safe passage of patients through a healthcare facility due to a number of factors influencing handovers, and, at the same time, that it is difficult to determine and introduce effective strategies to reduce the number of associated adverse events.

Hilligoss, Cohen (2013) draw attention to several factors influencing the context of handovers, including, in particular, the relative complexity of cases, the character and quality of the relationship between the parties participating in handovers, the disciplinary perspectives involved, and the nature of the communication media.

Answers to the following questions were sought:

Are approaches to communication during patient information handovers standardized?

How do the introduction of checklists and safety protocols influence the quality of information handed over, and patient safety?

\section{Methods}

\section{Design}

Descriptive summarizing study. 


\section{Sources}

To accomplish our aims, secondary data analysis was performed. PubMed, Science Direct, Embase and Google Scholar databases were studied.

\section{Search}

The key words handover, handoff, checklist, patient, and change-of-shift were used.

\section{Eligibility criteria}

Papers published in English over the past five years were focused on. In the period mentioned, 1,432 articles have been published.

\section{Data analysis and study selection}

Based on an extensive search, full texts of partial studies and discussion papers were included in the overview. The overview included papers dealing with the effectiveness of patient information transfer between members of staff, teams, and healthcare providers. Following analysis of available publications, we found that 28 articles corresponded with the main criterion, i.e., patient safety at patient handovers and transfers (handoffs). For gradual exclusion of studies, PRISMA recommendations were followed, as shown in Figure 1.

The level of the evidence was assessed in accordance with the Joanna Briggs Institute (JBI), since both qualitative and quantitative research is dealt with (Klugar, 2015). The evaluation included studies of evidence levels two, three, and four (two - quasiexperimental designs and qualitative or mixed synthesis methods, three - observational - analytic designs and qualitative methods of a primary research, four - observational - descriptive designs).

Theses or similar studies and papers on different topics, e.g., topics focusing on staff safety, dealing with emergent situations, teaching materials, etc., were excluded from our study. Similarly, papers that were not available as full texts, and papers that did not, after detailed analysis, contain sufficient relevant information were excluded.

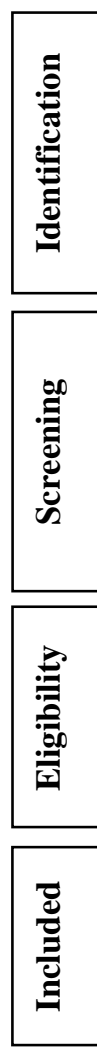

Records identified through database searching $(\mathrm{n}=1,432)$
Additional records identified through other sources $(\mathrm{n}=0)$

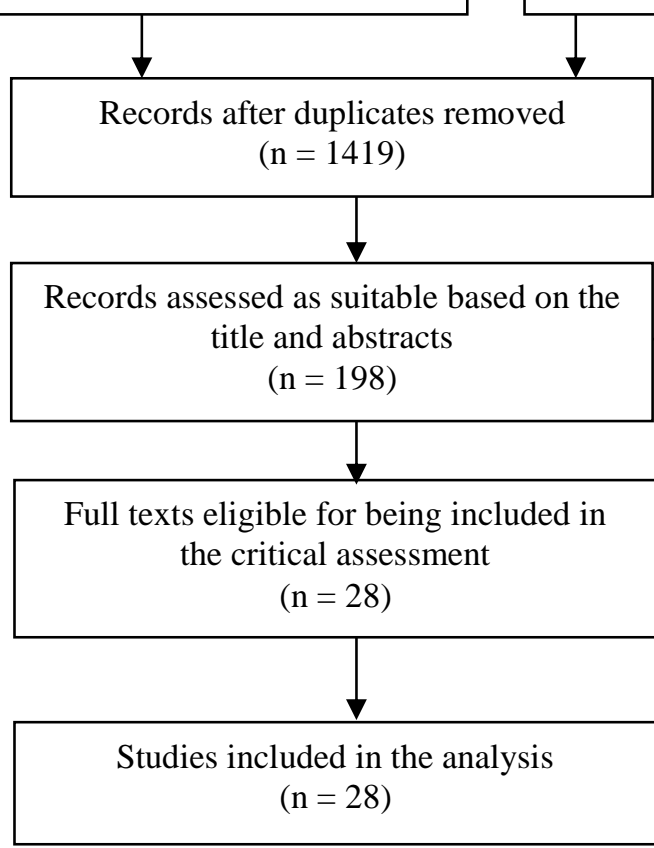

Figure 1 Flowchart - recommendation by PRISMA 


\section{Results}

The decisive feature distinguishing clinical handover from other patient communication is the transfer of responsibility or control from the communicator to the receiver. This also entails the need to briefly convey what it is necessary for the other party responsible for the next course of patient treatment to know, i.e., information on current health status, recent or expected changes, and the follow-up care the patient requires (Cohen, Hilligoss, 2010).

Non-effective communication at the handover creates the opportunity for the development of adverse events, since incomplete, incorrect or omitted data can produce ambiguity. Efforts to improve communication to ensure continuity of care and the quality of handed-over information may lead to the introduction of standardized protocols including mnemonic lists and checklists, which will become important tools for patient safety (Cohen, Hilligoss, 2010; Starmer et al., 2012; Hilligoss et al., 2013).

In a search of the literature, we found that in various combinations and models, the effectiveness of SBAR (Situation, Background, Assessment, Recommendation), I-PASS (Illness severity, Patient summary, Action list, Situation awareness and contingency planning, Synthesis by receiver), body system models, and models for trauma patients had been tested. The assessments of proposed standardized protocols were performed in various types of facilities, most frequently at ICUs (intensive care units) and emergency departments. An overview of the technologies is shown in Table 1 Part I and II.

Table 1 Characteristics of studies included in the analysis (Part I)

\begin{tabular}{|c|c|c|c|c|}
\hline Authors (year) & $\begin{array}{l}\text { Method of information handover } \\
\text { (content arrangement) }\end{array}$ & Clinical area & $\begin{array}{l}\text { Degree of the } \\
\text { evidence }\end{array}$ & $\begin{array}{l}\text { Number of participants, } \\
\text { handover sessions }\end{array}$ \\
\hline $\begin{array}{l}\text { Abraham et al. } \\
(2015)\end{array}$ & list of body systems & intensive care & 2 & $\begin{array}{l}16 \text { staff nurses, } 7 \text { patients, } \\
15 \text { handovers }\end{array}$ \\
\hline $\begin{array}{l}\text { Abraham et al. } \\
\text { (2013) }\end{array}$ & $\begin{array}{l}\text { HAND IT (list of body systems) } \\
\text { and SOAP (subjective and } \\
\text { objective assessment of patient } \\
\text { condition) }\end{array}$ & intensive care & 3 & 41 handovers per each tool \\
\hline $\begin{array}{l}\text { Achrekar et al. } \\
(2016)\end{array}$ & SBAR & unlimited & $3 c$ & 20 a 19 staff nurses \\
\hline $\begin{array}{l}\text { Arumugam et al. } \\
\text { (2016) }\end{array}$ & SBAR & standard ward & $2 c$ & 83 staff nurses \\
\hline $\begin{array}{l}\text { Ashcraft, Owen } \\
(2017)\end{array}$ & SBAR in an electronic record & $\begin{array}{l}\text { emergency, } \\
\text { standard ward, } \\
\text { nursing homes }\end{array}$ & $2 \mathrm{~d}$ & $\begin{array}{l}56 \text { persons in a control and } \\
\text { intervention group }\end{array}$ \\
\hline $\begin{array}{l}\text { Banihashemi et al. } \\
\text { (2015) }\end{array}$ & SBAR & intensive care & $4 b$ & $\begin{array}{l}45 \text { staff nurses and } 15 \\
\text { doctors }\end{array}$ \\
\hline $\begin{array}{l}\text { Birmingham, } \\
\text { Buffum, Blegen } \\
(2015)\end{array}$ & SBAR and list of systems & unlimited & 3 & 21 staff nurses \\
\hline $\begin{array}{l}\text { Blower et al. } \\
(2014)\end{array}$ & $\begin{array}{l}\text { electronic tool with recommended } \\
\text { RCSE (Royal College of } \\
\text { Surgeons) elements }\end{array}$ & surgical ward & $3 c$ & 118 a 114 handovers \\
\hline $\begin{array}{l}\text { Ebben et al. } \\
(2015)\end{array}$ & $\begin{array}{l}\text { DeMIST - demography, } \\
\text { mechanism of injury or illness, } \\
\text { symptoms, treatment }\end{array}$ & emergency & $3 c$ & $\begin{array}{l}88 \text { experts, } 314 \text { handovers } \\
\text { in two phases }\end{array}$ \\
\hline $\begin{array}{l}\text { Fabila et al. } \\
(2016)\end{array}$ & $\begin{array}{l}\text { SBAR - inclusion in the PETS } \\
\text { handover protocol }\end{array}$ & $\begin{array}{l}\text { cynaecology- } \\
\text { obstetrics, } \\
\text { intensive care unit }\end{array}$ & $3 e$ & 44 staff nurses \\
\hline $\begin{array}{l}\text { Heilman et al. } \\
\text { (2016) }\end{array}$ & IPASS & emergency & 2 & $\begin{array}{l}4 \text { control groups of } 4-8 \\
\text { persons each }\end{array}$ \\
\hline $\begin{array}{l}\text { Hesselink et al. } \\
\text { (2014) }\end{array}$ & IPASS & emergency & 3 & $\begin{array}{l}26 \text { dialogues and } 321 \\
\text { individual dialogues with } \\
\text { patients and SOs }\end{array}$ \\
\hline
\end{tabular}


Table 2 Characteristics of studies included in the analysis (Part II)

\begin{tabular}{|c|c|c|c|c|}
\hline Authors (year) & $\begin{array}{l}\text { Method of information handover } \\
\text { (content arrangement) }\end{array}$ & Clinical area & $\begin{array}{l}\text { Degree of the } \\
\text { evidence }\end{array}$ & $\begin{array}{l}\text { Number of participants, } \\
\text { handover sessions }\end{array}$ \\
\hline $\begin{array}{l}\text { Hunter et al. } \\
\text { (2017) }\end{array}$ & SBAR & $\begin{array}{l}\text { surgery, operating } \\
\text { room }\end{array}$ & 3 & 23 handovers \\
\hline $\begin{array}{l}\text { Inanloo, } \\
\text { Mohammadi, } \\
\text { Haghani (2017) }\end{array}$ & SBAR & intensive care & $2 \mathrm{c}$ & 53 staff nurses \\
\hline $\begin{array}{l}\text { Jain, Yadav } \\
(2017)\end{array}$ & SBAR & intensive care & $3 c$ & 120 persons \\
\hline $\begin{array}{l}\text { Kumar et al. } \\
\text { (2016) }\end{array}$ & SBAR & $\begin{array}{l}\text { neuro-scientific } \\
\text { centre }\end{array}$ & 3 & 525 handovers \\
\hline $\begin{array}{l}\text { LeBlanc et al. } \\
\text { (2014) }\end{array}$ & $\begin{array}{l}\text { standardized protocol for } \\
\text { traumatology handovers }\end{array}$ & $\begin{array}{l}\text { surgery, } \\
\text { orthopaedics }\end{array}$ & $4 b$ & 247 respondents \\
\hline $\begin{array}{l}\text { Lee, Desai, Phan } \\
\text { (2017) }\end{array}$ & SBAR & internal unit & 3 & $\begin{array}{l}30 \text { participants, } 134 \\
\text { handovers }\end{array}$ \\
\hline $\begin{array}{l}\text { Moore et al. } \\
(2017)\end{array}$ & $\begin{array}{l}\text { ISBAR (identification, situation, } \\
\text { background, assessment, } \\
\text { recommendation) }\end{array}$ & $\begin{array}{l}\text { community and } \\
\text { hospital facilities, } \\
\text { air service }\end{array}$ & $4 b$ & $\begin{array}{l}40 \text { and } 48 \text { phone records } \\
\text { (two and four per person) }\end{array}$ \\
\hline $\begin{array}{l}\text { Nagammal et al. } \\
\text { (2017) }\end{array}$ & SBAR & cancer centre & $4 b$ & 117 staff nurses \\
\hline $\begin{array}{l}\text { Lane-Fall et al. } \\
(2014)\end{array}$ & $\begin{array}{l}\text { SBAR, SOAP (subjective and } \\
\text { objective assessment of patient } \\
\text { condition) and format of standard } \\
\text { medical evidence }\end{array}$ & intensive care & 3 & 30 persons \\
\hline $\begin{array}{l}\text { Randmaa et al. } \\
\text { (2017) }\end{array}$ & $\begin{array}{l}\text { SBAR a control safety list in } \\
\text { surgery WHO }\end{array}$ & intensive care & 3 & 6 groups with 23 persons \\
\hline $\begin{array}{l}\text { Sujan et al. } \\
(2017)\end{array}$ & $\begin{array}{l}\text { ATMIST (age, time, and } \\
\text { mechanism if injury, primary } \\
\text { treatment) }\end{array}$ & $\begin{array}{l}\text { ambulance } \\
\text { service, } \\
\text { emergency }\end{array}$ & 3 & 203 handovers \\
\hline $\begin{array}{l}\text { Starmer et al. } \\
(2014)\end{array}$ & IPASS & paediatrics & $3 d$ & $\begin{array}{l}432 \text { handover documents, } \\
207 \text { sound records }\end{array}$ \\
\hline $\begin{array}{l}\text { Malekzadeh et al } \\
(2013)\end{array}$ & $\begin{array}{l}\text { Handover protocol according to } \\
\text { Joint Commission International } \\
\text { standards }\end{array}$ & intensive care & $2 \mathrm{~d}$ & 56 staff nurses \\
\hline $\begin{array}{l}\text { Ting et al. } \\
\text { (2017) }\end{array}$ & $\begin{array}{l}\text { SBAR } \\
\text { and standardized questionnaire for } \\
\text { SAQ (Safety Attitudes } \\
\text { Questionnaire) }\end{array}$ & obstetrics & $3 c$ & 29,34 a 33 staff nurses \\
\hline $\begin{array}{l}\text { Wollenhaup et al. } \\
\text { (2017) }\end{array}$ & $\begin{array}{l}\text { SBAR and a modified tool for } \\
\text { handovers }\end{array}$ & obstetrics & $3 c$ & $\begin{array}{l}28 \text { staff nurses, } 50 \\
\text { handovers }\end{array}$ \\
\hline Yu, Kang (2016) & SBAR & academic setting & $4 b$ & 137 persons \\
\hline
\end{tabular}

\section{Discussion}

$S B A R$ (or the modified ISBAR version) is, due to its brevity, suitable for situations demanding fast decision-making. It is recommended when handing over information between individual shifts or during patient transfers (Starmer et al., 2014; Moore et al., 2017).

Positive results of using SBAR in combination with other methods are described by Achrekar et al. (2016); Fabila et al. (2016); Kumar et al. (2016); Ting et al. (2017).
Improvements in the effectiveness of handovers, and healthcare staff's responsibility for patient safety are documented by a study evaluating SBAR components during report handovers. By integrating the tool, reliability improved from $54.5 \%$ to $83.73 \%$ (Arumugam et al., 2016). The study participants themselves mentioned that the use of mnemonic lists improved awareness and reduced discrepancies and errors (Arumugam et al., 2016; Fabila et al., 2016).

A Swedish group of experts failed to demonstrate any improvement in information handovers in postoperative care (Randmaa et al., 2017). 
The results of the study by Fabila et al. (2016) suggest that the new PETS (pre-handover, equipment, timeout, and sign out) protocol integrating the $S B A R$ form optimizes interdisciplinary communication and the passing on of important information between operating team members and pediatric ICU members at handovers. The construction of the new protocol reduced ambiguity, and facilitated the process of distinguishing between missing, and inadequate information.

I-PASS technology is an option for the transfer of information regarding complicated cases requiring wider information and context. The mnemonictechnology provides a framework for the process of patient handovers (I - importance of the disease; A - activity list; $\mathrm{S}-$ situation description; S - summarizing by the recipient). Starmer et al. (2014) performed an intervention study focusing on the degree of failure of nursing care processes, unintentional adverse events, and miscommunication. Implementation of the I-PASS Handoff Bundle includes mnemonic techniques for the standardization of verbal and written handovers, training in communication skills and team work, a didactic interactive workshop, stimulation training, a computer learning module, and materials and tools for a campaign to change culture. The evaluation results were based on assessment of handover records. The work procedures were assessed by observation. The number of medical errors was reduced by $23 \%$, and the rate of unintentional adverse events that could cause harm to patients was reduced by $30 \%$. The significant increase in the number of written documents and verbal communication at handovers improved communication without any negative impact on working methods.

The mnemonic characteristics of I-PASS may also be acceptable in urgent care workplaces (Heilman et al., 2016), after making certain modifications that take into account their dynamic nature and time constraints.

Mnemonic learning methods and structures for information transfer are also applied by tools based on the use of computer and web-operated systems. Options for their application are published, for example, by Cohen, Hilligoss (2010); Blower et al. (2014); Ebben et al. (2015); Jain, Yadav (2017).

The study published by Blower et al. (2014) has demonstrated a statistically significantly more efficient transmission process using electronic forms, thus improving patient safety, increasing the level and continuity of care, reducing the length of stay in hospital, and increasing the educational value of handover.
The structured HAND-IT (Handoff Intervention Tool), whose content categories are organized according to the importance and relevance for working procedures in intensive care (including physical examinations, laboratory tests, medication, diagnostic and therapeutic regimen for each body system) improves the ability of the handing-off staff to react quickly to the requirements and questions of the recipients, thereby accelerating problemsolving and decision-making processes (Abraham et al., 2013).

The main recommendations for using the DeMIST model (demographics, injury or disease mechanism, injury or disease, symptoms, treatment) stem from the ability to structure information received from prehospital care for handing over at urgent admissions. However, although the results of the study demonstrate a relatively high degree of suitability for use and the correct sequence, its use did not improve compliance with instructions for patient handover at urgent admissions, such as the transfer of responsibility between professionals, an uninterrupted transfer process, or verification that information was understood (Ebben et al., 2015).

The participants in the Swedish study felt that use of electronic records was complicated and timeconsuming, and resulted in the loss of overview of patients' conditions (Randmaa et al., 2017).

During the analysis of the literature, we found that a number of studies dealt with checklists and protocols. Calls for the standardization of structured information handovers are supported by a British randomized study. The suitability of checklists for handovers is explained by the fact that memory signals maintain recall of clinical information, especially in situations in which, due to even shortterm psychological fatigue and cognitive burden on healthcare professionals, information is lost (Flindall et al., 2016).

Evaluations of the effectiveness of handovers generally focus on three areas: structure, clinical content, and interruptions in communication. The structure of communication enables the identification of conversational strategies (cooperation) during patient information transfer and the development of a common base. The content of communication determines the clinical character of the dialogues.

Interruptions in communication are used as an alternative measure for communication gaps during the handover (Abraham et al., 2015).

Participants in the Swedish study confirmed that written information improved memory. As part of the introduced handover structure, they were expected 
not only to receive information, but also to ask questions in a structured way during the handover rather than after it had ended (Randmaa et al., 2017).

The introduction of standardized and structured protocols for shift information handovers leads to effective and regular communication, supports continuity of care (Malekzadeh et al., 2013), and prevents re-admissions to ICUs from standard units (van Sluisveld et al., 2017), and to hospital from primary care provision, etc. (Hesselink et al., 2014).

Malekzadeh et al. (2013) suggest adapting protocols to specific settings. The study, focusing on the introduction of a shift handover protocol to an ICU, improved the staff nurses' awareness of patient needs, and the quality of nursing care. Lane-Fall et al. (2014) draw attention to the fact that handover communication should reflect the various participants`roles, including differences in structure and content. Similarly, LeBlanc et al. (2014) recommend using standardized checklists that are specific to patient needs, to enable safe handovers. The results of the study demonstrate that to achieve patient safety during handovers, the most important aspects include: comorbidity, diagnosis, readiness for theatre, stability, mechanism of injury, and unresolved problems. They particularly recommend the preoperative checklist for orthopedic surgery.

On the other hand, correlations between the procedures performed during discharge from ICU (such as verbal and written handoffs, discharge planning, monitoring post injection treatment, education, etc.,) and the number of re-admissions to the ICU within 48 hours were not confirmed by a Dutch study (van Sluisveld et al., 2017).

Though more than $90 \%$ of respondents who participated in that questionnaire study regarded the checklist as useful, in the same group of respondents, negative attitudes to checklists were identified as an obstacle to their use (van Sluisveld et al., 2017).

We are aware that the presented overview of available literature is limited primarily by its focus, i.e., on areas relating to the transfer of information between staff, teams or care providers, in connection with clinical handovers or patient transfers.

\section{Conclusion}

Based on the study of available literature, we attempted to answer the question of whether in practice, standardized approaches to communication are used during patient handovers. Although our conclusions are not entirely unambiguous, it can be seen that mnemonic methods are quite widespread, and despite certain pitfalls arising, for example, from inappropriate use or neglect of certain parts by users, they appear to be effective, and there are efforts to apply them in electronic information handover.

As evidenced by the results the studies presented, the integration of standardized protocols may not, in itself, solve problems associated with information handovers. At protocol implementation, the general context of the communication model and possible barriers resulting from the character of the setting or excessive stress should be taken into consideration.

Information on the handover of patient information can be regarded as the starting point for further, more detailed studies that will focus more on the positive aspects of handover safety.

\section{Ethical aspects and conflict of interest}

The authors declare that the presented manuscript has been neither published nor offered for publication to any other publishers, and the development and publication of this paper do not cause any conflict of interests, and the article has not been supported by any firm.

\section{Author contribution}

Conception and design (RP, SB), data analysis and interpretation of data (RP), drafting the manuscript (RP), critical revision of the manuscript (SB), the final completion of the article (RP, SB).

\section{References}

Abraham J, Kannampallil TG, Almoosa KF, Patel B, Patel VL. Comparative evaluation of the content and structure of communication using two handoff tools: implications for patient safety. Journal of Critical Care. 2013;29(2):311.

Abraham J, Kannampallil TB, Brenner C, Lopez KD, Almoosa KF, Patel B, Patel VL. Characterizing the structure and content of nurse handoffs: A Sequential conversational analysis approach. Journal of Biomedical Informatics. 2015;59:76-88.

Achrekar MS, Murthy V, Kanan S, Shetty R, Nair M, Khattry $\mathrm{N}$. Introduction of situation, background, assessment, recommendation into nursing practice: a prospective study. Asia-Pacific Journal of Oncology Nursing. 2016;3(1):45-50. Arumugam Y, Hassan H, Putra P, Irwan S. Managing patient progress report through SBAR tool in non-critical areas. International Journal of Current Innovation Research. 2016;2(9):495-503.

Ashcraft AS, Owen DC. Comparison of standardized and customized SBAR communication tools to prevent nursing home resident transfer. Applied Nursing Research. 2017;38:64-69.

Banihashemi S, Hatam N, Zand F, Kharazmi E, Nasimi S, Askarian M. Assessment of three "WHO" Patient safety solutions: Where do we stand and What can we do? International Journal of Preventive Medicine. 2015;6:120. 
Birmingham P, Buffum MD, Blegen MA, Lyndon A. Handoffs and Patient Safety: Grasping the Story and Painting a Full Picture. Western Journal of Nursing Research. 2014;37(11):1458-1478.

Blower EL, MacCarrick T, Forster H, Sutton PA, Vimalachandran D. Implementation of a new tool to improve the efficacy and safety of surgical handovers. International Journal of Surgery. 2014;3(2015):189-192.

Brabcová I, Bártlová S, Gutkowska D, Ličeník R, Marková E, Nagórska M, Papp K, Pokojová R, Prošková E, Tóthová V, Zrubcová D. Management v ošetřovatelské praxi. 1. vyd. Praha: Nakladatelství lidové noviny; 2015. (in Czech)

Cohen MD, Hilligoss PB. The published literature on handoffs in hospitals: deficiencies identified in an extensive review. Quality and Safety in Health Care. 2010;19(6):493497.

Ebben RHA, van Grunsven PM, Moors ML, Aldenhoven P, de Vaan J, van Hout R, van Achterberg T, Vloet LCM. A tailored e-learning program to improve handover in the chain of emergency care: a pre-test post-test study. Scandinavian Journal of Trauma, Resuscitation and Emergency Medicine. 2015;23:33.

Fabila TS, Hee HI, Sultana R, Assam PN, Kiew A, Chan YH. Improving postoperative handover from anaesthetists to nonanaesthetists in a children's intensive care unit: the receiver's perception. Singapore Medical Journal. 2016;57(5):242-253. Flindall IR, Leff DR, Pucks N, Sugden C, Darzi A. The preservation of cued recall in the acute mentally fatigued state: a randomised crossover study. World Journal of Surgery. 2016;40(1):56-65.

Friesen MA, White SV, Byers JF. Handoffs: implications for nurses. In: Hughes RG, editor. Patient safety and quality: an evidence-based handbook for nurses. Rockville (MD): Agency for Healthcare Research and Quality (US); 2008. p. 285-322.

Halm MA. Nursing handoffs: Ensuring safe passage for patients. American Association of Critical Care. 2013;22(2):158-162.

Heilman JA, Flanigan M, Nelson A, Johnson T, Yarris LM. Adapting the I-PASS handoff program for emergency department Inter-shift handoffs. Western Journal of Emergency Medicine. 2016;17(6):756-761.

Hesselink G, Zegers M, Vernooij-Dassen M, Barach P, Kalkman C, Flink M, Öhlen G, Olsson M, Bergenbrant S, Orrego C, Suñol R, Toccafondi G, Venneri F, DudzikUrbaniak E, Kutryba B, Schoonhoven L, Wollersheim H; European HANDOVER Research Collaborative. Improving patient discharge and reducing hospital readmissions by using intervention Mapping. BMC Health Services Research. 2014; $14: 389$.

Hilligoss B, Cohen MB. The unappreciated challenges of between-unit handoffs: negotiating and coordinating across boundaries. Annals of Emergency Medicine. 2013;61(2):155160.

Horsky J, Suh EH, Sayan O, Patel V. Uncertainty, case complexity and the content of verbal handoffs at the emergency department. AMIA Annual Symposium Proceedings. 2015;2015:630-639.

Hunter H, Tara C, Wesley C, Juliane B, Susan H, Paula S, Sara E, Kevin L, Ji Yun K, Renaldo B. Assessing SBAR during intraoperative handoff. Perioperative Care and Operating Room Management. 2017;6:7-10.

Inanloo A, Mohammadi N, Haghani $\mathrm{H}$. The effect of shift reporting training using the SBAR tool on the performance of nurses working in intensive care units. Journal of Clientcentered Nursing Care. 2017;3(1):51-56.

Jain S, Yadav JA. Study on standardized system of shift handover communication compliance. International Journal of Advanced Research and Innovative Ideas in Education. 2017;3(4):3370-3377.

Klugar M. Kritické hodnocení vědeckých důkazů ve zdravotnictví. In Marečková J, Gurková E, Jarošová D, Klugarová J, Klugar M, Zeleníková R. Evidence-Based Health Care - Zdravotnictví založené na vědeckých di̊kazech. Olomouc: Univerzita Palackého v Olomouci: 2015. s. 34-61. (in Czech)

Kumar P, Jithesh V, Vij A, Gupta SK. Need for a hands-on approach to hand-offs: a study of nursing handovers in an Indian Neurosciences Center. Asian Journal of Neurosurgery. 2016;11(1):54-59.

Lane-Fall MB, Speck RM, Ibrahim SA, Shea JA, McCunn M, Bosk CL. Are attendings different? Intensivists explain their handoff ideals, perceptions, and practices. Annals of the American Thoracic Society. 2014;11(3):360-366.

LeBlanc J, Donnon T, Hutchison C, Duffy P. Development of an orthopedic surgery trauma patient handover checklist. Canadian Journal of Surgery. 2014;57(1):8-14.

Lee SH, Desai SV, Phan PH. The impact of duty cycle workflow on sign-out practices: a qualitative study of an internal medicine residency program in Maryland, USA. BMJ Open. 2017;7(5): e015762.

Machaczek K, Whietfield M, Kilner K, Allmark P. Doctors' and nurses' perceptions of barriers to conducting handover in hospitals in the Czech Republic. American Journal of Nursing Research. 2013;1(1):1-9.

Malekzadeh J, Mazluom SR, Etezadi T, Tasseri A. A standardized shift handover protocol: improving nurses' safe practice in intensive care units. Journal of Caring Sciences. 2013;2(3):177-185.

Moore M, Roberts Ch, Newbury J, Crossley J. Am I getting an accurate picture? A tool to assess clinical handover in remote settings. BMC Medical Education. 2017;17:213.

Nagammal S, Nashwan AJ, Nair SLK, Susmitha A. Nurses' perceptions regarding using the SBAR tool for handoff communication in a tertiary cancer center in Qatar. Journal of Nursing Education and Practice. 2017;7(4):103-110.

Perry SJ, Wears RL, Patterson ES. High-hanging fruit: improving transitions in health care. In: Henriksen K, Battles JB, Keyes MA, et al., editors. Advances in patient safety: new directions and alternative approaches. Rockville (MD): Agency for Healthcare Research and Quality (US); 2008. p. $1-9$.

Pokorná A, Štrombachová V, Búřilová P, Dolanová D. Taxonomický - definiční slovník pro Systém hlášení nežádoucích událostí (SHNU). Praha: ÚZIS; 2017. [cited 2017 Dec 03]. Avaliable from: http://shnu.uzis.cz/res/file/FINAL_shnu-taxonomienovy_verze_1_2017.pdf (in Czech)

Randmaa M, Engström M, Swenne CL, Martensson G. The postoperative handover: a focus group interview study with nurse anaesthetists, anaesthesiologists and PACU nurses. BMJ Open. 2017;7(8): e015038.

Starmer AJ, Spector ND, Srivastava R, Allen AD, Landrigan CP, Sectish TC, I-PASS study group. I-PASS, a mnemonic to standardize verbal handoffs. Pediatrics. 2012;129(2):201204.

Starmer AJ, Spector NJ, Srivastava R, West DC, Rosenbluth G, Allen AD, Noble EL, Tse LL, Dalal AK, Keohane CA, 
Lipsitz SR, Rothschild JM, Wien MF, Yoon CS, Zigmont KR, Wilson KM, O'Toole JK, Solan LG, Aylor M, Bismilla Z, Coffey M, Mahant S, Blankenburg RL, Destino LA, Everhart JL, Patel SJ, Bale JF, Jr., Spackman JB, Stevenson AT, Calaman S, Cole FS, Balmer DF, Hepps JH, Lopreiato JO, Yu CE, Sectish TC, and Landrigan CP, for the I-PASS Study Group. Changes in medical errors after implementation of a handoff program. New England Journal of Medicine. 2014;371:1803-1812.

Sujan MA, Chessum P, Rudd M, Fitton L, Inada-Kim M, Spurgeon P, Cooke MW. Emergency Care Handover (ECHO study) across care boundaries: the need for joint decision making and consideration of psychosocial history. Emergency Medicine Journal. 2015;32(2):112-118.

Ting WH, Peng FS, Lin HH, Hsiao SM. The impact of situation-background-assessment-recommendation (SBAR) on safety attitudes in the obstetrics department. Taiwanese Journal of Obstetrics and Gynecology. 2017;56(2):171-174. van Sluisveld N, Oerlemans A, Westert G, van der Hoeven JG, Wollersheim H, Zegers M. Barriers and facilitators to improve safety and efficiency of the ICU discharge process: a mixed methods study. BMC Health Services Research. 2017;17:251.

Věstník Ministerstva Zdravotnictví České republiky, 2015, část 16, s. 2-30. (in Czech)

Wollenhaup CA, Stevenson EL, Thompson J, Gordon HA, Nunn G. Implementation of a modified bedside handoff for a postpartum unit. Journal of Nursing Administration. 2017;47(6):320-326.

Yu M, Kang K. SBAR report competency and communication clarity of handover in Korean nursing students. International Journal of Bio-Science and BioTechnology. 2017;7(6):189-200.

Zákon č. 372/2011 Sb., o zdravotních službách a podmínkách jejich poskytování. Sbirka zákonů 6.11 .2011 , roč. 2011, částka 131. (in Czech) 